\title{
Impact of traffic routes on the content of trace elements in soils in Warsaw agglomeration
}

\begin{abstract}
This article presents the results of a study on the content of selected trace metals $(\mathrm{Pb}, \mathrm{Zn}, \mathrm{Cu}, \mathrm{Cd})$ in soils near the main traffic routes of the Warsaw agglomeration. The aim of the study was to determine the extent of soil contamination with trace metals at different distances from the road (by the side the road and 50 meters away from the road). In the soil $50 \mathrm{~m}$ away from the road in Łomianki 'low contamination' was found for zinc and 'elevated content' for copper according to the IUNG guidelines, but the amounts of the trace elements were not found to exceed the permissible levels as specified in the Regulation of the Minister for the Environment of 1 September 2016.
\end{abstract}

Keywords: trace elements, traffic routes, Warsaw agglomeration

\section{INTRODUCTION}

Transport is one of the sectors of the economy in which very dynamic development can be observed (Kordel 2016). The growing affluence of people is largely reflected in the increase in financial investments in tangible goods, such as the means of road transport (Kozanecka et al. 2000, Biernat and Syta 2008, Szyszlak-Bargłowicz et al. 2013, Walczak and Chutko 2014). The intensification of the movement of vehicles, especially on the exit roads from large urban agglomerations, causes traffic paralysis, the so called traffic jams. A consequence of this for the environment is the emission of toxic pollutants in the form of fumes and road dust containing trace elements that pose the most serious threat to the soils in the vicinity of traffic routes (Potarzycki et al. 1999, Hofman and Wachowski 2010, Czubaszek and Bartoszuk 2011, Szyszlak-Bargłowicz et al. 2013).

The content of trace elements in the soils in the neighbourhood of traffic routes is caused by (Malczyk and Kędzia 1996, Greinert and Greinert 1999, Forman et al. 2003, Bomze et al. 2007, Czubaszek and Bartoszuk 2011): organic compounds formed as a result of incomplete combustion of fuels, organic and mineral compounds used to supplement the composition of fuels and lubricants, material produced by the wearing of tyres, asphalt and heavily used automotive parts (brake linings and clutch discs), trace elements used to supplement fuels- $\mathrm{Pb}$, oils and lubricants (e.g. $\mathrm{Cu}, \mathrm{Zn}, \mathrm{Cd}$ ), leakage from damaged tanks and batteries, volatile compounds from exhaust pipes (e.g. $\mathrm{SO}_{2}, \mathrm{NO}_{\mathrm{x}}$ ), salt used for de-icing road surfaces and pavements.

The heavier gases and dust fall onto the roadway and the soil in the immediate vicinity, while the lighter ones are carried away over larger distances. The factors influencing the movement of pollutants from the atmosphere into the soil include atmospheric precipitation and wind intensity (Niedbała et al. 2010).

The trace elements contaminating the soil inhibit the activity of microorganisms living in it, thereby contributing to a reduction in their vital functionsdecomposition and transformation of organic substances (Becker et al. 2006, Hander et al. 2012, OciepaKubicka and Ociepa 2012). The limited microbial activity in the rhizosphere has a negative effect on plants, inhibiting their normal growth and adversely affecting their resistance (Meers et al. 2007). The form in which the trace elements are present affects their mobility and availability to plants. Using the resources of the soil through the root system, plants take up various elements, including heavy metals, which in turn causes the heavy metals to become part of the trophic chain (Fijałkowski et al. 2012, Grobelak et al. 2013).

The aim of the study was to assess the extent of soil pollution with trace elements near the main exit roads from Warsaw, depending on the distance from the road. 


\section{MATERIALS AND METHODS}

Analysis of soil samples for selected trace elements $(\mathrm{Pb}, \mathrm{Cd}, \mathrm{Zn}, \mathrm{Cu})$ was carried out for soils located near the exit roads from Warsaw, about $10 \mathrm{~km}$ past the city limits. The transects were shown in Table 1 and Figure 1.

With the aim of assessing the variation in the content of trace elements in the soil with distance, soil samples were taken at right angles to the edge of the road in close proximity to the traffic route and 50 meters away from the road, from the surface layer of the soil (0$0.25 \mathrm{~m}$ ). The sampling sites included the roadside strip $(0 \mathrm{~m})$ and wasteland $(50 \mathrm{~m})$. The soil samples were dried to an air-dry state. They were then ground in a porcelain mortar and sieved through a sieve with a mesh diameter of $2 \mathrm{~mm}$.

The soil samples were analyzed for: $\mathrm{pH}$ - by the potentiometric method in $1 \mathrm{~mol} \cdot \mathrm{dm}^{-3} \mathrm{KCl}$ solution using a SCHOTT $\mathrm{pH}$ meter, content of selected heavy metals: $\mathrm{Cu}, \mathrm{Pb}, \mathrm{Cd}, \mathrm{Zn}$ after extraction in $1 \mathrm{~mol} \cdot \mathrm{dm}^{-3} \mathrm{HCl}$ - by atomic absorption spectrometry (AAS) using a Thermo Elemental SOLAAR M6 spec-

TABLE 1. Traffic routes, soil sampling sites, and annual average daily traffic (vehicles per day)

\begin{tabular}{|c|c|c|c|c|}
\hline Item & $\begin{array}{l}\text { Road } \\
\text { No. }\end{array}$ & Route & $\begin{array}{l}\text { Soil } \\
\text { sampling } \\
\text { site } \\
\text { (Fig. 1) }\end{array}$ & $\begin{array}{l}\text { Annual } \\
\text { average daily } \\
\text { motor-vehicle } \\
\text { traffic* }\end{array}$ \\
\hline 1 & 7/E77 & Gdańsk-Chyżne & Sękocin & 23458 \\
\hline 2 & 79 & Warszawa-Katowice & Żabieniec & 30075 \\
\hline 3 & 7/E77 & Gdańsk-Chyżne & Łomianki & 52466 \\
\hline 4 & $\mathrm{~S} 8 / \mathrm{E} 67$ & Suwałki-Wrocław & Marki & 43874 \\
\hline 5 & 2/E30 & Kukuryki-Ś wiecko & Terespol & 22082 \\
\hline
\end{tabular}

* Based on GDDKiA data (gddkia.gov.pl)

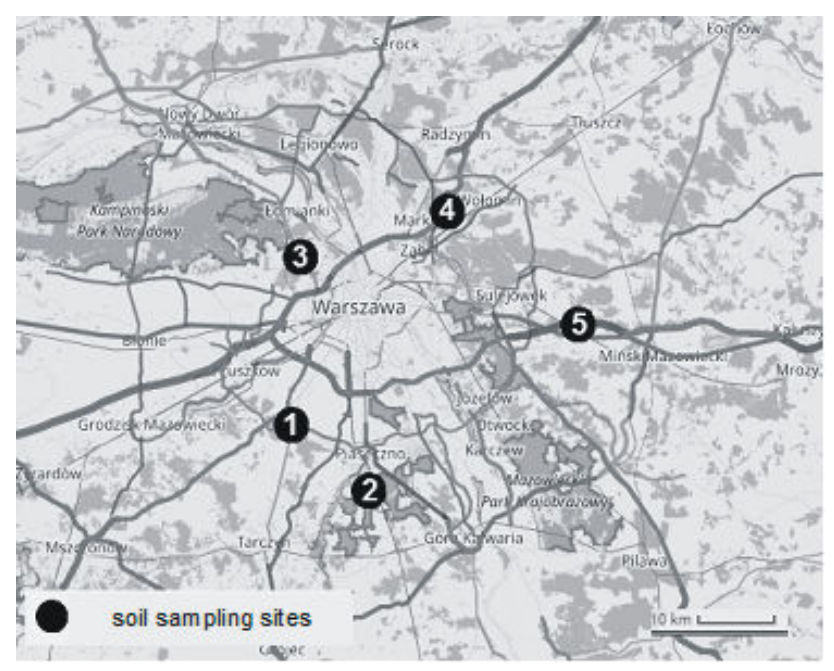

FIGURE 1. Location of the soil sampling sites near the main exit roads from Warsaw (mapa.siskom.waw.pl) trometer, the total contentof selected heavy metals: $\mathrm{Cu}, \mathrm{Pb}, \mathrm{Cd}, \mathrm{Zn}$ after wet mineralization in $14 \mathrm{ml}$ of reverse aqua regia using a Milestone ETHOS-PLUS Microwave Labstation by atomic absorption spectrometry (AAS) using a Perkin-Elmer 2100 spectrophotometer.

The results were statistically analyzed using the method of one-way analysis of variance at a significance level of $p=0.05$.

\section{RESULTS AND DISCUSSION}

The total permissible content of trace elements in wasteland soils (Class III) ranges from 10-1000 $\mathrm{mg} \cdot \mathrm{kg}^{-1}$, and in soils near public roads (Class IV) 15-2000 $\mathrm{mg} \cdot \mathrm{kg}^{-1}$ (Regulation of the Minister for the Environment of 1 September 2016). Comparing the amounts of heavy metals in the analyzed samples with the current Regulation, it is found that they do not exceed the permissible levels for either wasteland soils or those next to public roads. Taking into account the natural levels of trace elements in soils classified as sands (for $\mathrm{Zn}-59.0 \mathrm{mg} \cdot \mathrm{kg}^{-1}, \mathrm{Cu}-23.5$ $\left.\mathrm{mg} \cdot \mathrm{kg}^{-1}, \mathrm{~Pb}-21.0 \mathrm{mg} \cdot \mathrm{kg}^{-1}, \mathrm{Cd}-1.0 \mathrm{mg} \cdot \mathrm{kg}^{-1}\right)(\mathrm{Czar}-$ nowska 1996), elevated values were observed for the soils in Łomianki $\left(\mathrm{Pb}-81.0 \mathrm{mg} \cdot \mathrm{kg}^{-1}, \mathrm{Cu}-41.4\right.$ $\left.\mathrm{mg} \cdot \mathrm{kg}^{-1}, \mathrm{Zn}-246.0 \mathrm{mg} \cdot \mathrm{kg}^{-1}\right)$, in Sękocin $(\mathrm{Cu}-49.7$ $\left.\mathrm{mg} \cdot \mathrm{kg}^{-1}, \mathrm{Zn}-191.0 \mathrm{mg} \cdot \mathrm{kg}^{-1}\right)$ and in Żabieniec ( $\mathrm{Zn}$ $-102.0 \mathrm{mg} \cdot \mathrm{kg}^{-1}$ ) (Table 2). The remaining results fluctuated around the natural limits, or represented the natural content. Similar results for the lead content of soils next to National Road 7 had been obtained by Gworek et al. (2011). The highest amounts of trace elements were accumulated by the soil in Łomianki in close proximity to the edge of the roadway, and the lowest amounts by the soil in Terespol.

With increasing share of the form extracted in $1 \mathrm{~mol} \cdot \mathrm{dm}^{-3} \mathrm{HCl}$ in the total heavy metals content in the soil their bioavailability to plants and mobility also increases (Niesiobędzka and Krajewska 2008). The average share of the form extracted in $1 \mathrm{~mol} \cdot \mathrm{dm}^{-3}$ $\mathrm{HCl}$ in the total heavy metals content in the soil changed in the following order: $\mathrm{Cd}<\mathrm{Zn}<\mathrm{Cu}<\mathrm{Pb}$ (Table 3). Similar relations had been obtained by Badora (1993).

The content of the lead form extracted in 1 $\mathrm{mol} \cdot \mathrm{dm}^{-3} \mathrm{HCl}$ was in the range $9.02-23.78 \mathrm{mg} \cdot \mathrm{kg}^{-1}$. The highest accumulation of this element was found in the soil in close proximity to the road in Sękocin $\left(23.78 \mathrm{mg} \cdot \mathrm{kg}^{-1}\right)$ and in the sample of soil $50 \mathrm{~m}$ away from the road in Łomianki (23.27 $\left.\mathrm{mg} \cdot \mathrm{kg}^{-1}\right)$. The lead content in the soils at the roadside and $50 \mathrm{~m}$ away varied significantly, with the excep- 
TABLE 2. Total heavy metals content in soil $\left(\mathrm{mg} \cdot \mathrm{kg}^{-\mathbf{1}}\right)$

TABLE 3. Share of the form extracted in $1 \mathrm{~mol} \cdot \mathrm{dm}^{-3} \mathrm{HCl}$ in the total heavy metals content in soil (\%)

\begin{tabular}{|c|c|c|c|c|c|c|c|c|}
\hline \multirow{3}{*}{$\begin{array}{l}\text { Sampling } \\
\text { location }\end{array}$} & \multicolumn{2}{|l|}{$\mathrm{Pb}$} & \multicolumn{2}{|l|}{$\mathrm{Cd}$} & \multicolumn{2}{|l|}{$\mathrm{Cu}$} & \multicolumn{2}{|l|}{$\mathrm{Zn}$} \\
\hline & 0 & 50 & 0 & 50 & 0 & 50 & 0 & 50 \\
\hline & $\mathrm{m}$ & & & & & & & \\
\hline Sękocin & 25.0 & 16.0 & 1.0 & 0.6 & 49.7 & 9.1 & 191 & 72 \\
\hline Żabieniec & 21.0 & 15.0 & 0.9 & 0.9 & 23.4 & 10.6 & 102 & 45 \\
\hline Łomianki & 81.0 & 28.0 & 0.7 & 0.6 & 41.4 & 36.6 & 246 & 44 \\
\hline Marki & 13.0 & 15.0 & 0.3 & 0.8 & 7.9 & 15.5 & 41 & 59 \\
\hline Terespol & 25.0 & 24.0 & 0.4 & 0.4 & 11.3 & 11.8 & 36 & 44 \\
\hline $\begin{array}{l}\text { Permissible } \\
\text { levels* } \\
\text { (Dz.U. 2016, } \\
\text { poz. 1395) }\end{array}$ & 600 & 500 & 15 & 10 & 600 & 300 & 2000 & 1000 \\
\hline
\end{tabular}

\begin{tabular}{|c|c|c|c|c|c|c|c|c|}
\hline \multirow[t]{3}{*}{ Sampling location } & \multicolumn{2}{|l|}{$\mathrm{Pb}$} & \multicolumn{2}{|l|}{$\mathrm{Cd}$} & \multicolumn{2}{|l|}{$\mathrm{Cu}$} & \multicolumn{2}{|l|}{$\mathrm{Zn}$} \\
\hline & \multicolumn{8}{|l|}{$\mathrm{m}$} \\
\hline & 0 & 50 & 0 & 50 & 0 & 50 & 0 & 50 \\
\hline Sękocin & 93 & 77 & 24 & 48 & 56 & 53 & 8 & 5 \\
\hline Żabieniec & 89 & 87 & 19 & 13 & 45 & 43 & 23 & 32 \\
\hline Łomianki & 26 & 85 & 20 & 56 & 16 & 84 & 12 & 45 \\
\hline Marki & 79 & 65 & 25 & 19 & 96 & 33 & 55 & 6 \\
\hline Terespol & 36 & 55 & 21 & 19 & 47 & 58 & 37 & 34 \\
\hline
\end{tabular}

tion of the soil samples from Marki, where the values were similar for both samples (Fig. 2).The all analyzed soil samples did not exceed the levels of lead recognized as natural content (Kabata-Pendias 1993, Kabata-Pendias et al.1995).

The contentof the cadmium form extracted in $1 \mathrm{~mol} \cdot \mathrm{dm}^{-3} \mathrm{HCl}$ was in the range $0.08-0.34 \mathrm{mg} \cdot \mathrm{kg}^{-1}$. The highest accumulation of this element was found in the soil $50 \mathrm{~m}$ away from the road in Łomianki $(0.34$ $\mathrm{mg} \cdot \mathrm{kg}^{-1}$ ), and the lowest near National Road 2 and Expressway S8 $\left(0.08 \mathrm{mg} \cdot \mathrm{kg}^{-1}\right)$. The cadmium content in the soils at the roadside and $50 \mathrm{~m}$ away varied significantly, with the exception of the soil samples collected by the side of S8, where the values were similar for both samples (Fig. 3). The analyzed soil samples did not exceed the cadmium levels recognized as natural content (Kabata-Pendias 1993, Kabata-Pendias et al.1995).

The contentof the copper form extracted in $1 \mathrm{~mol} \cdot \mathrm{dm}^{-3} \mathrm{HCl}$ was in the range $4.53-28.04 \mathrm{mg} \cdot \mathrm{kg}^{-1}$. The highest accumulation of this element was found in the soil $50 \mathrm{~m}$ away from the road in Łomianki (28.04 $\mathrm{mg} \cdot \mathrm{kg}^{-1}$ ), and the lowest in the soils $50 \mathrm{~m}$ away from the roads in Sękocin, Żabieniec and Marki, and in the soil sample by the side of No. 2 road (4.53-6.49 $\left.\mathrm{mg} \cdot \mathrm{kg}^{-1}\right)$. The levels of copper in the soils by the side of the road and $50 \mathrm{~m}$ away differed significantly in all locations (Fig. 4). The analyzed soil samples exceed the $\mathrm{Cu}$ levels recognized as natural for the soil 50 $\mathrm{m}$ away from the road in Łomianki and for the roadside soil in Sękocin. These soils characterized of first degree $\left(\mathrm{I}^{\circ}\right)$ contamination with copper - elevated content (Kabata-Pendias 1993, Kabata-Pendias et al.1995).
FIGURE 2. Soil lead content depending on the distance from the road.

Explanations: $\mathrm{a}, \mathrm{b}$ - different letters indicate significant differences for distance from the road

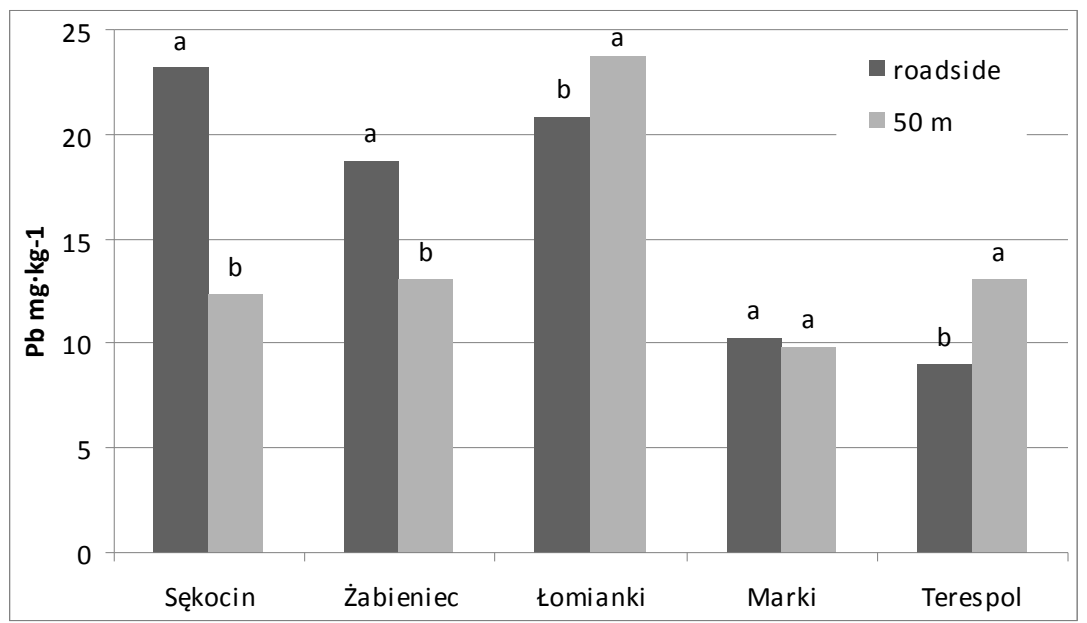



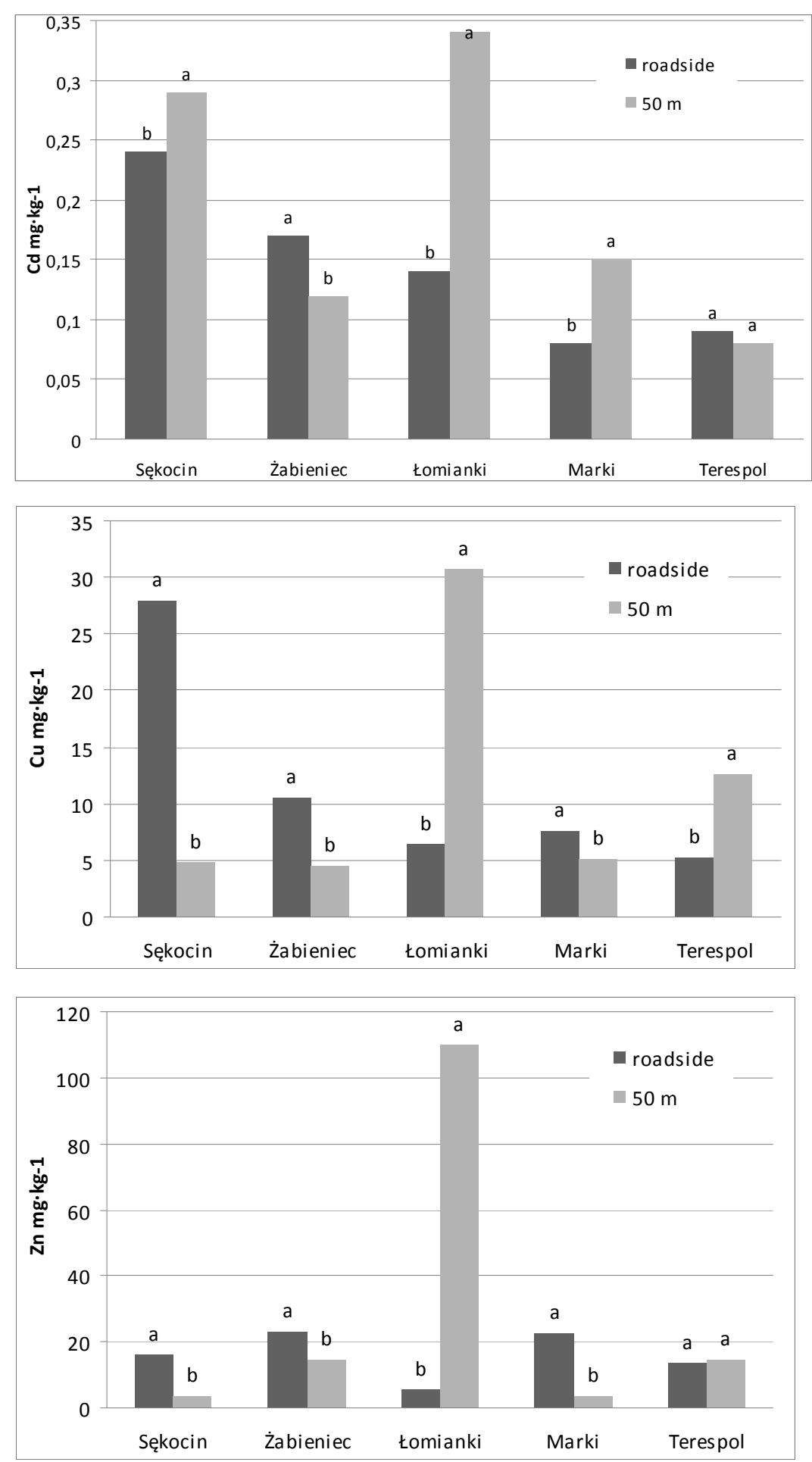

FIGURE 3. Soil cadmium content depending on the distance from the road. Explanations: $\mathrm{a}, \mathrm{b}$ - different letters indicate significant differences for distance from the road

FIGURE 4. Soil copper content depending on the distance from the road.

Explanations: $\mathrm{a}, \mathrm{b}$ - different letters indicate significant differences for distance from the road

FIGURE 5. Soil zinc content depending on the distance from the road. Explanations: $\mathrm{a}, \mathrm{b}$ - different letters indicate significant differences for distance from the road

The content of the zinc form extracted in $1 \mathrm{~mol} \cdot \mathrm{dm}^{-3}$ $\mathrm{HCl}$ was in the range $3.32-109.98 \mathrm{mg} \cdot \mathrm{kg}^{-1}$. The highest accumulation of this element was found in the soil $50 \mathrm{~m}$ away from the road in Łomianki (109.98 $\mathrm{mg} \cdot \mathrm{kg}^{-1}$ ), and the lowest in the soils $50 \mathrm{~m}$ away from the roads in Sękocin and Marki. The zinc content in the soils near the road and $50 \mathrm{~m}$ away varied significantly, with the exception of soil samples collected near the S8, where the values were similar for both samples (Fig. 5).The analyzed soil samples exceed the level of $\mathrm{Zn}$ recognized as natural for the soil $50 \mathrm{~m}$ away from the road in Łomianki. The soil is classed as second-degree $\left(\mathrm{II}^{\circ}\right)$ contamination with zinc - low contamination (Kabata-Pendias 1993, Kabata-Pendias et al.1995). 
The accumulation of trace elements in the soils adjacent to the main exit traffic routes from Warsaw is directly related to the volume of traffic (Potarzycki et al. 1999). The highest levels of harmful pollutants were found in the soils from Łomianki, where the annual average daily traffic of vehicles is the heaviest, and the lowest near National Road 2, where traffic volume is the smallest. During peak hours, difficulties arise in the smooth passage of vehicles on the exit roads, which is associated with higher emissions of pollutants, particularly lead. Many older cars are not equipped with catalytic converters for reducing emissions of exhaust gases harmful to the environment (Hofman and Wachowski 2010). The dominant winds in Poland are from the directions $\mathrm{W}, \mathrm{NW}$ and SW (geomatura.pl 2017), which means that pollutants are carried away mainly east of the roads. This relationship is particularly evident in the soils from Łomianki. The sampling site represented an area where there were no barriers to the free movement of air masses, which contributed to the accumulation of lead, copper, zinc and cadmium in larger quantities in the soil $50 \mathrm{~m}$ away from the road than in the immediate proximity of it.

\section{CONCLUSIONS}

1. The proximity of express roads contributes to the accumulation of trace elements in soil but the content of these elements in soil samples near exit roads from Warsaw usually did not exceed the permissible values.

2. The soil near the road in Łomianki is most exposed to anthropopressure and $50 \mathrm{~m}$ away from the road the soil was characterized low contamination by zinc and elevated content for copper.

3. The share of trace elements extracted by $1 \mathrm{~mol} \cdot \mathrm{dm}^{-3}$ $\mathrm{HCl}$ in relation to the total content in the soil indicates that the most mobile is lead and the least mobile is cadmium.

\section{REFERENCES}

Badora A., 1999. Mobilne formy wybranych metali w glebach oraz niektóre aspekty ich immobilizacji. Rozprawa habilitacyjna. Rozprawy Naukowe Akademii Rolniczej w Lublinie (225). Wydawnictwo Akademii Rolniczej w Lublinie: 12-14.

Becker J.M., Parkin T., Nakatsu C.H., Wilbur J.D., Konopka A., 2006. Bacterial activity, community structure and centimeterscale spatial heterogeneity in contaminated soil, Microbial. Ecol. 51: 221-231.

Biernat K., Syta A., 2008: Analiza wpływu budowy i eksploatacji infrastruktury drogowej na czynniki abiotyczne i biotyczne środowiska. [W:] Studia Ecologiale et Bioethicae 6/2008: 287-306.
Bomze K., Rutkowska B., Szulc W., 2007. Zawartość pierwiastków śladowych w mniszku pospolitym (Taraxacum officinale) w zależności od odległości od trasy komunikacyjnej. Roczniki Gleboznawcze - Soil Science Annual 58(3-4): 38-42.

Czarnowska K., 1996. Ogólna zawartość metali ciężkich w skałach macierzystych jako tło geochemiczne gleb. Roczniki Gleboznawcze - Soil Science Annual 47: 43-50.

Czubaszek R., Bartoszuk K., 2011. Zawartość wybranych metali ciężkich w glebach w zależności od ich odległości od ulicy i sposobu użytkowania terenu. [W:] Civil and Environmental Engineering 2: 27-34.

Fijałkowski K., Kacprzak M., Grobelak A., Placek A., 2012. The influence of selected soil parameters on the mobility of heavy metals in soil. Inżynieria i ochrona środowiska 15 (1): 81-92.

Forman R.T., Sperling D., Bissonette J. i wsp., 2003. Road Ecology: Science and Solutions. Island press, Waszyngton.

Greinert H., Greinert A., 1999. Ochrona i rekultywacja środowiska glebowego. Wydawnictwo Politechniki Zielonogórskiej, Zielona Góra.

Grobelak A., Kacprzak M., Grosser, A., Napora, A., 2013. Chemofitostabilizacja gleby zanieczyszczonej kadmem, cynkiem i ołowiem. Rocznik Ochrona Środowiska 15: 1982-2002.

Gworek B., Dabrowski P., Poniecka B., Wrzosek J., 2011. Effect of road traffic on soil and plant contamination with mercury. Przemysł Chemiczny 90(2): 267-270.

Hander K., Dyckmans J., Joergensen R.G., Meyer B., Raubuch M., 2012. Different Sources of heavy metals and their long-term effects on soil microbial properties, Biol. Fertil. Soils 34: 241247.

Hofman M., Wachowski L., 2010. Badania zawartości platyny i ołowiu w glebie wzdłuz głównych dróg wylotowych z Poznania. Ochrona Środowiska 32(3): 43-47.

Kabata-Pendias A., 1993. Ocena stopnia zanieczyszczenia gleb i roślin metalami ciężkimi i siarką. Ramowe wytyczne dla rolnictwa. IUNG. Puławy.

Kabata-Pendias A., Piotrowska M., Matowicka-Terelak T., Maliszewsk-Kordybach B., Filipiak K., Krakowiak A., Pietruch C., 1995. Podstawy oceny chemicznego zanieczyszczenia gleb. Metale ciężkie, siarka i WWA. Biblioteka Monitoringu Środowiska. PIOŚ. IUNG. Warszawa: 7-28.

Kordel Z., 2016. Effectiveness of the road transport market. Logistyka 3: 113-120.

Kozanecka T., Czarnowska K., Kwasowski W., 2000. Nagromadzenie metali ciężkich w glebach w otoczeniu stacji benzynowych w Warszawie. Roczniki Gleboznawcze - Soil Science Annual 1(51): 73-78.

Malczyk P., Kędzia W., 1996. Metale ciężkie w glebach leśnych wzdłuż drogi wylotowej Bydgoszcz-Inowrocław. Roczniki Gleboznawcze - Soil Science Annual 3(47): 203-211.

Meers E., Samson R., Tack F.M.G., Ruttens A., Vandegehuchte M., Vangronsveld J., Verloo M.G., 2007. Phytoavailability assessment of heavy metals in soils by single extractions and accumulation by Phaseolus vulgaris, Environ. Experim. Bot. 60: 385-396.

Niedbała M., Smolińska B., Król-Domańska K., 2010. Zanieczyszczenia gleb miejskich miasta Łodzi wybranymi pierwiastkami śladowymi, Chemia Spożywcza i Biotechnologia 74, 1081: 29-38.

Niesiobędzka K., Krajewska E., 2008. Metale ciężkie w układzie gleba-roślinność w środowisku wielkomiejskim. Ekotoksykologia w Ochronie Środowiska, PZIiTS, Oddział Dolnośląski, Wrocław: 265-270. 
Ociepa-Kubicka A., Ociepa E., 2012. Toksyczne oddziaływanie metali ciężkich na rośliny, zwierzęta i ludzi. Inżynieria i ochrona środowiska 15: 169-180.

Potarzycki J., Grzebisz W., Biber M., Diatta J.B., 1999. Stan geochemiczny gleb i jakość płodów rolnych w strefie oddziaływania trasy komunikacyjnej Poznań-Świecko. Rocz. AR. Pozn., CCCX, Melior. Inż. Środow. 20(1): 77-85.

Rozporządzenie Ministra Środowiska z dnia 1 września 2016 r. w sprawie sposobu prowadzenia oceny zanieczyszczenia powierzchni ziemi (Dz.U. 2016, poz. 1395).

Szyszlak-Bargłowicz J., Słowik T., Zając G., Piekarski W., 2013. [W:] Metale ciężkie w rowach odwadniających ciagów komunikacyjnych. Rocznik Ochrona Środowiska (Annual Set The Environment Protection) 15: 2309-2323.
Walczak B., Chutko T., 2014. Zawartość miedzi w glebie w różnych odległościach od krawędzi jezdni drogi krajowej nr 3 w okolicach Nowego Miasteczka. Zeszyty Naukowe. Inżynieria Środowiska / Uniwersytet Zielonogórski 155(35): 95-105. website 1:http://mapa.siskom.waw.pl/

website 2: https://www.gddkia.gov.pl/userfiles/articles/g/general ny-pomiar-ruchu-w-2015_15598//SYNTEZA/MAPA_SDR R2015 DK.pdf

website $3: \bar{h}$ ttp://www.geomatura.pl/index.php/geografia-polski3/57-wiatry-w-polsce

Received: March 20, 2017

Accepted: April 18, 2017

Associated editor: B. Rutkowska

\section{Ocena oddziaływania ciągów komunikacyjnych na zawartość pierwiastków śladowych w glebach na przykładzie aglomeracji warszawskiej}

Streszczenie: W pracy przedstawiono wyniki badań zawartości wybranych metali śladowych $(\mathrm{Pb}, \mathrm{Zn}, \mathrm{Cu}, \mathrm{Cd}) \mathrm{w}$ glebach przy głównych ciagach komunikacyjnych aglomeracji warszawskiej. Celem przeprowadzonych badań było określenie stopnia zanieczyszczenia gleb metalami śladowymi w różnych odległościach od drogi, to jest bezpośrednio przy drodze $(0 \mathrm{~m})$ i $50 \mathrm{metrów}$ od drogi. W glebie oddalonej o $50 \mathrm{~m}$ od jezdni w Łomiankach stwierdzono słabe zanieczyszczenie dla cynku i podwyższoną zawartość dla miedzi zgodnie z wytycznymi IUNG, natomiast nie stwierdzono przekroczenia dopuszczalnych zawartości pierwiastków śladowych zgodnie z Rozporządzeniem Ministra Środowiska z dnia 1 września 2016 roku.

Słowa kluczowe: pierwiastki śladowe, ciągi komunikacyjne, aglomeracja warszawska 